DOI https://doi.org/10.36059/978-966-397-142-1/69-86

\title{
CLAIM OF NORMS OF INTERNATIONAL LAW BY NATIONAL COURTS
}

\section{Ivanchenko O. M.}

\section{INTRODUCTION}

The problem of the interaction of international and national law is central to the theory of international law, since its research allows to reveal the essence of both legal systems, the basis of their existence and development. Their interconnection has grown so much in recent decades that in some cases, deciding which of the two systems is decisive in regulating any relationship is of great difficulty. Moreover, the question of how the norms of one system affect the formation and development of the norms of another becomes especially relevant. The resolution of these issues is decisive for the whole sphere of action, not only international but also domestic law.

In view of the comprehensive development of integration processes in the world, international law is a key element in the development of domestic legal systems. Achieving the goals of world security, peace and the interconnected development of states depends on the quality of the system of international and national (domestic) law.

International cooperation and its rapid development in various spheres of both public and public life make the use of the rules of international law by the states more and more necessary to coordinate their actions in different fields, including in the field of ensuring both international and national security of states. As noted by E.T. Usenko, many experts in the field of national law are increasingly working with categories of international law, and experts in international law with categories of national law ${ }^{1}$.

Speaking about the correlation between international and national law, II Lukashuk noted that, as developing, international law strengthens interaction with national law and is determined by the internationalization of public life. At the same time, the interconnection and unity of the world require that the national political and legal systems of the world be built as

${ }^{1}$ Усенко Е. Т. Соотношение категорий международного и национального (внутригосударственного) прав. Советское государство и право. 1983. № 10. С. 45. 
part of a single global system, to ensure interaction with each other and with the system of international relations as a whole. According to him, many internal problems depend on interaction with the external environment ${ }^{2}$.

Currently, scholars take a different approach to the relationship between international and domestic $\mathrm{law}^{3}$. Some are defined by the category of relation, others by interaction ${ }^{4}$.

The independence of these systems of law is determined by the subject composition, the object of regulation, the method of establishing mutual rights and obligations ${ }^{5}$. However, independence does not mean independence, the absence of any interdependence. These systems of law are closely linked.

Instead, the question of the relation, interaction, application, harmonization, application and application of international rules in national law has been covered in many studies by experts in the field of international law.

\section{The main theoretical approaches to the impact of international law on national law and order}

Among the doctrinal approaches to the correlation of international and national law, over the last two centuries, several generalized concepts have been elaborated, which are traditionally divided into the theories of monism and the theory of dualism. In turn, the monistic approach is divided into two opposing trends: the primacy of international law and the primacy of national law.

In 1899, the German researcher W. Kaufman, in his work "The Legal Power of International Law and the Relationship of the Legislature and State Bodies", laid out the basic principles of the theory of monism, which was subsequently developed by G. Kelsen. This theory assumes the existence of a single universal system of law, which covers the rule of law at different levels. All law develops within the so-called "basic norm",

2 Лукашук И.И. Международное право. Общая часть : учебник. Москва : Норма, 2004. C. 224, 264-267.

${ }^{3}$ Блищенко И. П. Международное и внутригосударственное право. Москва: Госюриздат, 1960. С. 87.

${ }^{4}$ Международное право : учебник / отв. ред. Г.В. Игнатенко, О.И. Тиунов. Москва : Норма, 2006. С. 124.

${ }^{5}$ Шуміленко А. П. Міжнародні механізми імплементації норм міжнародного права у сфері боротьби з торгівлею жінками : автореф. дис. ...канд.. юрид. наук : спец. 12.00.11. Одеса, 2010. С. 12. 
which, in G. Kelsen's view, "is the introduction of fundamental circumstances of lawmaking and can be defined, in this sense, as a constitution in a legal and logical sense, as opposed to a constitution in the positive- the legal meaning of the word". International law has priority over other rules of law. It occupies the top of the normative hierarchical pyramid and determines the legal validity of other law and order. Law and order can only be based on international law, which is the legal basis of all subsequent acts of the state ${ }^{6}$. According to G. Kelsen, the correlation between the norms of international law and the norms of national law is similar to the correlation between national law and order and national norms of a corporation.

Asserting the primacy of international law, G. Kelsen views state sovereignty as the freedom of action of a state defined by international law. The international rule of law is based on the so-called "positive (virtually established) norm", which G. Kelsen ${ }^{7}$ defines as follows: living in this territory and controlled by this government, constitutes a state (in the sense of international law)".

The opposite concept - the concept of the primacy of national law was developed by German followers G. Hegel (Malberg, Eichelman, Simson, Zorn). For Hegel, the state was an absolute value over which no norms could stand. Malberg wrote: "The state adheres to the rules, guided by its own will, and international law and international society - anarchy, the order in which the state contributes, restricting itself". Continuing this view, A. Zorn said: "international norms are legal norms when they manifest themselves as an integral part of national law". The primacy of national law was followed by a number of pre-revolutionary n lawyers NO Bezborodov, OO Eichelman, EK Simson, and also during the Soviet period developed by A. Ya. Vyshinsky. Today, this concept is rejected by the science of international law as essentially nihilistic, but in the practice of some states there are cases of recognition of the actual priority under national law.

The theory of dualism was created by the German scientist G. Trippel. The scientist has distinguished two main differences between international and national law: 1) subjects of national law are individuals, whereas subjects of international law are only states; 2) the source

6 Кельзен Г. Чисте правознавство / пер. 3 нім. О. Мокровольського. Київ : Юніверс, 2004. С. 221.

7 Там само. С. 366. 
of national law is exclusively the will of the state, while the source of international law is the general will of the states. According to Triple, in order for international law to be able to fulfill its task, it must constantly seek the assistance of national law.

The well-known Italian international lawyer A. Cassese holds the same opinion. Therefore, international law cannot function without the continued assistance, assistance and support of national legal systems.

The doctrine of dualism holds that international law does not depend on the will of a particular state, since it expresses the universal will of all states. Each State is bound to honor its international legal obligations. However, it is up to the state to determine how it will implement these obligations. In its legal system, it may even prioritize national law over international law. Of course, this may impose state responsibility, but this responsibility will be of a purely international legal character and will in no way be of legal value to the domestic legal system.

Among the new theories, the theory of harmonization proposed by the English professor J. Fitzmores in 1957, also known as the "Fitzmoris compromise", is worthy of consideration. He drew attention to the fact that the application of foreign law under national law is more or less similar to the application of international law in the national legal system, when foreign law is applied to the extent that it does not contradict national law of the state. It follows from Fitzmoris's theory that national judges cannot apply international law without the sanction laid down by national law. Similarly, international arbitrators and judges apply national law only to the extent that it does not contravene international law. In general, Fitzmoris believes, there is a tendency to harmonize national legal systems and international law. National lawyers, for example, interpret and develop national legal acts, taking into account the international obligations of their country, and international lawyers draft international legal acts, taking into account the specificities of national laws. On this basis, Fitzmaurice's theory is known as "harmonization theory".

The theories of monism and dualism are abstract, but very important in scientific terms. The choice between monism and dualism influences not only the understanding of the relation between international and national law, but also the understanding of the nature of international law (whether it is exclusively consensual, or creates a compulsory basis for all law and order), the nature of state sovereignty (whether it is absolute, or limited), the essence of the recognition of states (whether it is declaratory or constitutional), the place of the individual in international law (whether 
he is a subject or object of international law). The dispute between monism and dualism is, in fact, not so much through the proof of the reality of the "direct effect" of international law, but rather through the interpretation of the fundamental principles of international law ${ }^{8}$.

Thus, the nature of the influence of international law on national law in the doctrine and practice of international law has developed three classical approaches - dualistic theory and two varieties of monistic theory, under the influence or in the context of which a number of other theories have subsequently been developed.

One of the important practical aspects of the relation between international and national law is the question of the procedure for the fulfillment by the state of international contractual and customary obligations in its territory. The monistic concepts of the correlation of the two law and order presuppose the direct application of the rules of international law in the national legal system. Other conceptual directions explain differently the essence of the process of implementation of international legal norms in the national sphere. From the standpoint of modern international law, there is no doubt about the binding force of States on the generally recognized principle of "pacta sunt servanda", but it is generally accepted that the state, in accordance with its law, independently determines how it fulfills its international legal obligations.

\section{Legal and technical aspects of entry into international law into national law and order}

International law as a result of international law is a phenomenon of social reality. The last quarter of a century has clearly demonstrated the tendency for international and national law to converge against the backdrop of increasing integrative processes in the modern world. And the stronger the interdependence of states, the more important is the ordering factor in the system of international relations. Accordingly, the role of international law to ensure this order is growing. In this connection, it should be emphasized that international law does not support a certain socially necessary order of international relations, not some abstract and unchanging one, but rather a given one. In today's context, it is an order that ensures peace and cooperation. The new rule of law in the world requires the approximation of national legal decisions, on the one hand,

${ }^{8}$ Іванченко О. М. Співвідношення норм міжнародного і національного права : дис. ... канд. юрид. наук : спец. 12.00.01. Одеса, 2011. С. 75. 
and the formation of mechanisms for the development of concerted and joint decisions in the world community, on the other.

Among the many approaches to this issue are the following:

The mechanism of action of national law is not suitable for regulating international relations, international law is not capable of regulating national relations. In order to be able to regulate relations with the participation of individuals and legal entities, the rules contained in international law must be included in the legal system of the country in the order established by it. The process of entering international law into the legal system - "implementation", "transformation" - is a means of implementation.

When considering the problem of the influence of national law on international law, many such complex issues arise: analysis of the rules of national law in terms of their compliance with international law, the possibility of investigating national law as a major, preliminary or ancillary issue for an international court decision, the legal significance of national law law in international litigation and the fundamental question of the competence of international judicial institutions to resolve cases applying national law.

There are two opposing points of view in international law in this regard. Proponents of the dualistic theory of the relation between national law and international law believe that international judicial institutions have no right to apply national law in their decisions, because national legal acts in terms of international law are simple facts that have no legal value in international legal process.

On the basis of systematic unity, representatives of monistic theory have come to the conclusion that international courts are not only entitled, but in certain cases, bound to resolve issues of both international and national nature by applying national law.

An analysis of the theory and practice of universal judiciary on this issue leads to the conclusion that such international judicial authorities are incompetent to apply national law in the international legal process. National law cannot be a source of international law, since in the field of international law there is no subject of law that could be directed by national law.

There is also no substantive scope for national law in international relations. The rules of international law can only refer to elements of national law. 
On the other hand, international judicial institutions are competent to use the provisions of national law in their decisions as an auxiliary instrument used as a legal fact.

An analysis of the practice of such international courts also indicates that international courts often have to study national legal instruments to determine the true intentions of the parties or to examine national law to determine compliance with international law. The State cannot evade the fulfillment of voluntary international obligations by reference to the provisions of national law.

States' obligation to align their national law with international law stems from the basic principles and rules of modern international law. International courts may consider the compatibility of national laws with international law and international obligations arising from applicable international treaties. However, such a study is only possible when the parties request an immediate inquiry into such a study, or when the international court concludes that the reason for the violation of international law lies in the implementation by the State of certain national legal acts ${ }^{9}$.

The only legitimate result of a declaration of incompatibility of provisions of national law with international law is the state's international legal responsibility for failure to fulfill its voluntary international obligations, which was the cause of national law.

In making recommendations for the modernization of the legal and technical nature of the processes of harmonization and correlation of norms, it is very important to consider the constitutional, legal and judicial practice of individual states regarding the correlation of international and national law.

In the countries of "common law" national courts in the XVIII XIX centuries. made decisions on the interaction between national law and international law. In the states of the Romano-German legal system, this problem is mentioned in national legislation, and, first of all, in constitutional law - from the second half of the twentieth century.

The process of implementation by the state of international legal obligations and harmonization of international law and national law is divided into: transformation, incorporation, reception, dispatch.

${ }^{9}$ Попович В. І. Імплементація норм міжнародного гуманітарного права у кримінальне законодавство України : автореф. дис. ... канд. юрид. наук : спец. 12.00.08. Львів, 2010. С. 8. 
Researchers on the impact of international law on national point to the existence of contradictions in this issue. First, there is no consensus on the terminology used. For example, some authors refer to the "transformation" as the process of reconciliation. Others believe that transformation is only one way (amongst others) of implementing international law within the country ${ }^{10}$.

There is also no consensus on the nature and scope of the transformation. Some include the notion of transformation of dispatch, ratification, publication of the treaty, the issuance of special laws, administrative orders ${ }^{11}$. E.T. Usenko refers to the transformation as "an objective phenomenon, which is expressed in various ways of fulfilling the international obligations of the state by issuing it national legal acts". Other researchers highlight along with the transformation and reference or point to the reception and transformation. ${ }^{12}$

According to the two systems of law, the main task is to align already established norms. The methods of harmonization of national legal acts with international legal include: sending, reception, parallel lawmaking, unification, transformation ${ }^{13}$. Scientists also introduce into scientific circulation the notion of "implementation" ("domestic-state implementation", "national implementation", "domestic-legal implementation". Also proposed to use the term "sanctioning." acquired the concepts of "harmonization" and "adaptation ${ }^{14 " .}$

It should be noted that, in a general theoretical sense, the diversity of thoughts on this problem is a natural state for science.

The term "transformation" is conditional, because in essence the rules of international law do not lose their inherent legal nature. Transformation is to ensure that the state fulfills its international obligations through its powers. If the wording of the law is consistent with the provisions of an international agreement, it is incorporation. If a national law states

${ }^{10}$ Шутак I. Техніко-юридичні методи узгодження національного і міжнародного права. Вісник Національної академії прокуратури України. 2009. № 1. С. 93.

11 Левин Д. Б. Актуальные проблемы теории международного права. Москва: Юрид. лит., 1974. С. 92.

12 Усенко Е. Т. Соотношение и взаимодействие международного и национального права и Российская Конституция. Московский журнал международного права. 1995. № 2. С. 16.

13 Тихомиров Ю. А. Глобализация: взаимовлияние внутреннего и международного права. Журнал российского права. 2002. № 11. С. 5-6.

14 Васильев А. М. О системах советского и международного права. Советское государтво и право. 1985. № 1. С. 70-71. 
individually or collectively that in the case of differences between the rules of national law and the rules of international treaty, the rules of international law apply, this is a reference ${ }^{15}$.

In the legal literature, there are several types or forms of transformation of international law into national law. ETUsenko believes that all types of transformation can be divided into two types: general and special. General transformation consists in the establishment by the state in national law of a common law that gives international legal norms the force of domestic state action. The special transformation is to provide the state with specific rules of international law of internal state status by reproducing them in the law textually or in the form of provisions adapted to national law, or by legislative harmonization of their application in another way ${ }^{16}$.

Transformation can take place directly, which implies, for example, the application of international law within national law, when it follows from rules enshrined in the constitution or other normative legal acts that provide for the primacy of international law over national law. This form of transformation is called direct transformation. In particular, Article 9 of the Constitution of Ukraine states: "International treaties, the consent of which by which the Verkhovna Rada of Ukraine has been bound, are part of the national legislation of Ukraine ${ }^{17}$." Thus, their direct effect is sanctioned along with the current legislation of Ukraine.

International standards are based on international treaties, as well as international mechanisms designed to implement these standards at national and international levels.

It seems more appropriate to refer to the relation between international and national law through the category "interaction", since K. The category "relation" does not fully reflect the interdependence of international and national law. The connection between international and national law is manifested in the stages of law-making and enforcement, so the relationship between international and national law is more clearly manifested in the interaction rather than in the relation ${ }^{18}$.

\footnotetext{
${ }^{15}$ Ануфриева Л. П. Международное частное право : в 3 т. Москва : БЕК, 2000. Т. 1: Общая часть. С. 218.

${ }^{16}$ Усенко Е. Т. Соотношение и взаимодействие международного и национального права и Российская Конституция. Московский журнал международного права. 1995. № 2. С. 16-17.

17 Конституці України : прийнята на п’ятій сесії Верховної Ради України 28 червня 1996 р. Відомості Верховної Ради України. 1996. № 30. Ст. 141.

18 Лучинин А. Л. Особенности механизма имплементации европейского права : автореф. дис. ... канд. юр. наук : 12.00.10. Казань, 2006. С. 8.
} 
The interaction of international and national law is interdependent, which means that the implementation of international law can not be done without the help of national law, as well as the latter has significant difficulties in functioning without the rules of international law. Turning to the issue of promoting the rules of international law and the implementation of national law, it should be noted that international law becomes a legal condition for the implementation of many rules of national law of the state.

The interaction of the normative component of international law with national criminal law occurs in ways that are determined by the national legislator, and the processes occurring in legal studies in different terms: "transformation", "implementation", "harmonization", "incorporation", "adaptation", " implementation".

The term "implementation" literally means "implementation in accordance with a specific procedure", "ensuring the practical result and actual implementation by specific means". The term implementation has been developed in international law and has become widespread in numerous UN General Assembly resolutions, in many international conventions and treaties. In the broadest sense, the implementation of international law is nothing more than a process in which the entities to which the rule is addressed act in accordance with its provisions. Often, States require additional legal and organizational measures to fully and fully implement international law. I.I. Lukashuk noted that "implementation of international legal norms is, as a rule, much more difficult and responsible than adopting them. The solution to this problem is possible only if there is an optimal mechanism of implementation as a certain set of legal and organizational means used by the subjects of international law at the international and national levels for the purpose of translating the prescriptions of the rules of international law. In most cases, the implementation of international law is the prerogative of sovereign states that use their domestic legal mechanism for this purpose.

According to some scholars, the implementation of international law into national law is a set of international rules governing the joint legal activity of subjects of international law aimed at achieving the goals set out in international obligations ${ }^{19}$.

19 Лукашук И. И. Международно-правовое регулирование международных отношений (системный подход). Москва : Междунар. отношения, 1975. С. 10, 16. 
V. Ya. Suvorov states that "the term" implementation "has the right to exist as a synonym for the term" implementation ", that is, the implementation of rules in the practical activity of the state and other entities." 20 In turn, A.S. Hoverdowski by implementation means "purposeful organizational and legal activity of states, used individually, collectively or within the framework of international organizations, with a view to timely and complete implementation of their obligations under international law ${ }^{21}$." At the same time, SV Chernychenko believes that the term "implementation" can be used to refer to "the impact of international law on domestic relations through domestic law ${ }^{22 " .}$

The implementation of the rules of international law is nothing more than a process in which the relevant entities to which the rule is addressed act in accordance with its provisions ${ }^{23}$. Often, the state requires the adoption of additional legal and organizational measures to comprehensively and fully implement the rules of international law. In most cases, the implementation of international law is the prerogative of sovereign states that use their domestic legal framework for this purpose ${ }^{24}$.

Researchers distinguish between two processes that differ in subjects, content of actions and outcome - international law and national implementation of international legal norms, which mediate two mechanisms of implementation, interacting and complementing each other: international legal mechanism of implementation and domestic State mechanism for implementation of international law.

National law is the main instrument for the implementation of international law. The first legal stage in the process of implementation of international law is the reception by national law of the rules of international treaties. There are two main types of reception: general reception; partial reception. The general reception is the provision in the constitutions of states that international treaties are part of national law.

${ }^{20}$ Суворова В. Я. Обеспечение реализации договорных норм международного права (юридическая природа). Советское государство и право. 1991. № 9. С. 116.

${ }^{21}$ Гавердовский А. С. Имплементация норм международного прав. Киев : Вища шк., 1980. С. 63.

${ }^{22}$ Черниченко С. В. Международное право: современные теоретические проблемы. Москва : Междунар. отношения, 1993. С. 102.

${ }^{23}$ Курносова Т. И. Имплементация международно-правовых норм о военных преступлениях и преступлениях против человечности : автореф. дис. ... канд. юрид. наук : спец. 12.00.08. Москва, 2016. С. 18.

${ }^{24}$ Буткевич В. Г., Мицик В. В., Задорожній О. В. Міжнародне право. Основи теорії : підручник. Київ Либідь, 2002. С. 435. 
Partial (individual) reception can take the form of incorporation or transformation - a specific reference ${ }^{25}$.

Incorporation is the incorporation into national systems of law of norms, which are perfectly identical to the norms of international law. In most cases, the said international legal act retains its form, name, though it acts as a law.

The rules of international law in the national sphere are implemented either indirectly or directly, that is, have direct effect. Thus, the 1949 Geneva Convention applies to such international treaties, a considerable number of rules of which have direct effect. At the same time, irrespective of the ways of implementation of international norms in the national system of law, a state is obliged to take the necessary measures to harmonize its domestic law with obligations under international law, namely - it must supplement, amend, repeal those national legal acts that prevent fulfillment of its obligations under international law. According to the UN Charter, its members have undertaken to "create conditions under which justice and respect for obligations arising from treaties and other sources of international law can be respected". In Art. 27 of the Vienna Convention on the Law of Treaties states that a party may not invoke the provisions of its domestic law as an excuse for not fulfilling the treaty ${ }^{26}$.

The concept of implementation. The implementation of the rules of international law is a purposeful legal activity of the states, carried out individually, collectively or within the framework of international organizations with the aim of timely, comprehensive and full implementation of their obligations in accordance with international law. In case of implementation of international legal norms at the national level, additional national measures are needed to transform the goals set out in the norms of international law into real actions of legal entities and citizens under state jurisdiction.

Transformation is not only a reproduction, but also a revision of the rules of an international treaty in accordance with the general principles of national law. The legal result of transformation, in contrast to incorporation, is not only the addition of existing national law, but also the change of norms in accordance with the requirements of an international agreement.

${ }^{25}$ Устав Организации Объединенных Наций : принят 26.06.1945 г. URL: http://zakon.rada.gov.ua/laws/show/995_010 (дата звернення: 21.08.2016).

${ }^{26}$ Віденська конвенція про право міжнародних договорів : прийнята 23.05.1969. URL: http://zakon.rada.gov.ua/laws/show/995_118 (дата звернення: 20.20.2017). 
Transformation refers to the process of bringing a national law into conformity with international law in order to enforce orders, permits and prohibitions established by international law. Transformation does not imply change of international norms. International norms, since their adoption, are valid only in the sphere of interstate relations, they do not change their nature and cannot change. In order to ensure the implementation of such norms, the State shall, if necessary, apply the necessary national legal norms ${ }^{27}$.

Incorporation is a formal "incorporation" of the rules of an international treaty into the national law of the state. In essence, a new law or by-law is adopted that is completely identical to the international treaty - name, structure, wording, etc.

Legalization - the adoption of a special national act to ensure the implementation of state rules of international law. Such a national act does not follow all the external features of a relevant international legal act.

The term "dispatch" refers to an indication in national law that certain behavior of public authorities, officials, citizens is governed by general provisions or specific rules of treaties of international law. Departure, as an independent form of transformation, means the application, in accordance with the provisions of national law, of the rules established by international treaties or customs. However, national relations are governed not by the norm of international law but by the normative norms of a national legal act.

Referral is a formulation of a model of behavior in one system of law, in another system only indicates the source where the model can be viewed. As a result, the behavior model is one, and specific relationships and actors are different, which results in different rules and regulations.

Unification as a method of harmonization is a process of directional action to harmonize uniform provisions in international law and national law.

Transformation as a method of harmonization is the introduction of amendments, additions and clarifications to national legislation.

It is important to highlight the "transformational norm" - the rule according to which national law is harmonized with international law in order to implement the latter. Such rules include rules of national law which fix the priority of the rules of an international treaty over national

27 Большой юридический словарь / под ред. А. Я. Сухарева, В. Е. Крутских. 2-е изд., перераб. и доп. Москва : ИНФРА-М, 2004. С. 354. 
laws, and those which establish the obligation of the state to treat international treaties as part of national law ${ }^{28 .}$

In turn, "harmonization" is the organizational and political activity of states and other entities to create common forms of regulations and implement them in accordance with the rules of both legal systems. Harmonization is a two-way process of bringing national law into line with international law. The essence of the process lies not only in the comparison but also in the consistent harmonization of international law and national law.

There is no universal rule in international law that requires the harmonization of national law with international law, but has become a standard rule that requires such harmonization. This provision is based on case studies of special issues, international and national jurisprudence.

Therefore, each sovereign state independently determines the order of interaction of its national law with international law. It is enshrined in national law, above all, by the constitutional norms that reflect the philosophy of the regime and the nature of the legal understanding of this society. In order to regulate in a state the relations contained in an international treaty, the rules must enter into the legal system of the state in due course. In national law, international treaties can act indirectly and directly. The indirect effect of the contract involves the issuance of acts that specify its provisions. With the direct effect of an international treaty, there is no need for such acts. On the basis of the above, it can be argued that in the relation of national and international law and law in general, the Constitution of Ukraine takes into account the monistic theory, since the Basic Law fixes the provisions for the incorporation of existing international treaties, the consent of which is provided by the Verkhovna Rada, as part of it, where the highest priority is the Constitution. Their implementation is envisaged in the manner established for the rules of national law.

\section{CONCLUSIONS}

The correlation between the rules of international and national law is defined as a complex historically formed relatively stable system of interaction, mutual influence and interdependence of different rules of socially significant behavior by the subjects of law. The interaction of

${ }^{28}$ Великий енциклопедичний юридичний словник / за ред. Ю. С. Шемшученка. Київ : Юрид. думка, 2007. С. 439. 
national and international is a coordinated action of two legal systems, conditioned by the existence of common goals for them necessary for their mutual development, which does not exclude the possibility of their existence in common or separate spheres of activity. In addition, interaction is characterized by the mutual influence of these legal orders.

International law influences national law through harmonization and implementation mechanisms. Thus, the components of the interaction mechanism are the implementation mechanism and the coordination mechanism, which are implemented at the national level.

There are several models of the correlation of international and national law in the national legal system: according to the first model, the constitutions of states define the most general procedure for the correlation of international and national law, indicating that universally recognized principles and rules of international law are part of the national legal system; according to the second model, in the constitutions of the states, together with the general wording, specifies how the norms of international and national law are correlated with the legal force; According to the third model, only the norms of ratified international treaties are recognized as an element of the national legal system and no mention is made of the so-called generally recognized principles and rules of international law.

The most effective cognitive tool in the study of the relationship between international law and national law is the integrative concept of realistic positivism, according to which law is a regulatory and security system consisting of general rules (rules) adopted to ensure social stability, security, development and effective impact on public relations.

It seems that the existence of different models of correlation between the norms of international and national law in the national legal system is not a sign of any national identity of states. The reason lies more in the level of legal culture associated with different perceptions of international law as an integral part of national law. Unification in this direction is possible by formulating recommendations that are appropriate internationally.

\section{SUMMARY}

In theory, the application of international law in national legal systems is often explained in terms of the doctrines of incorporation and transformation. According to the incorporation doctrine, international law is automatically incorporated into national law ipso facto and may be 
applied by national courts. The "doctrine of transformation", on the other hand, indicates that international law is not ipso facto part of national law, but becomes so only after the adoption of the relevant act at the legislative level. Traditionally, the doctrines of incorporation and transformation correlate with the theories of monism and dualism. Thus, according to the theory of monism, international law and national law are part of the same rule of law, and this is reflected in the fact that international law is automatically incorporated into national law. Dualism theory views international law and national law as two separate systems of law.

It can be concluded that, while the incorporation of international law into national court decisions is not yet a common practice, the globalizing world dictates the rules under which the interconnection of international and national law is being strengthened, and this requires judges around the world to study international law. and foreign jurisprudence and have taken it into account when resolving domestic legal disputes.

\section{REFERENCES}

1. Усенко Е.T. Соотношение категорий международного и национального (внутригосударственного) прав. Советское государство и право. 1983. № 10. С. 45.

2. Лукашук И.И. Международное право. Общая часть : учебник. Москва : Норма, 2004. С. 224, 264-267.

3. Блищенко И.П. Международное и внутригосударственное право. Москва : Госюриздат, 1960. С. 87.

4. Международное право : учебник / отв. ред. Г.В. Игнатенко, О.И. Тиунов. Москва : Норма, 2006. С. 124.

5. Шуміленко А.П. Міжнародні механізми імплементації норм міжнародного права у сфері боротьби з торгівлею жінками : автореф. дис. ...канд.. юрид. наук : спец. 12.00.11. Одеса, 2010. С. 12.

6. Кельзен Г. Чисте правознавство / пер. 3 нім. О. Мокровольського. Київ : Юніверс, 2004. С. 221.

7. Кельзен Г. Чисте правознавство / пер. 3 нім. О. Мокровольського. Київ : Юніверс, 2004. С. 366.

8. Іванченко О.М. Співвідношення норм міжнародного i національного права : дис. ... канд. юрид. наук : спец. 12.00.01. Одеса, 2011. С. 75.

9. Попович B.I. Імплементація норм міжнародного гуманітарного права у кримінальне законодавство України: автореф. дис. ... канд. юрид. наук : спец. 12.00.08. Львів, 2010. С. 8. 
10. Шутак I. Техніко-юридичні методи узгодження національного і міжнародного права. Вісник Національної академії прокуратури України. 2009. № 1. С. 93.

11. Левин Д.Б. Актуальные проблемы теории международного права. Москва : Юрид. лит., 1974. С. 92.

12. Усенко Е.Т. Соотношение и взаимодействие международного и национального права и Российская Конституция. Московский журнал международного права. 1995. № 2. С. 16.

13. Тихомиров Ю.А. Глобализация: взаимовлияние внутреннего и международного права. Журнал российского права. 2002. № 11. С. 5-6.

14. Васильев А.М. О системах советского и международного права. Советское государтво и право. 1985. № 1. С. 70-71.

15. Ануфриева Л. П. Международное частное право : в 3 т. Москва : БЕК, 2000. Т. 1: Общая часть. С. 218

16. Усенко Е.Т. Соотношение и взаимодействие международного и национального права и Российская Конституция. Московский журнал международного права. 1995. № 2. С. 16-17.

17. Конституці України: прийнята на п'ятій сесії Верховної Ради України 28 червня 1996 р. Відомості Верховної Ради України. 1996. № 30. Ст. 141.

18. Лучинин А.Л. Особенности механизма имплементации европейского права : автореф. дис. ... канд. юр. наук : 12.00.10. Казань, 2006. С. 8.

19. Лукашук И.И. Международно-правовое регулирование международных отношений (системный подход). Москва : Междунар. отношения, 1975. С. 10, 16.

20. Суворова В.Я. Обеспечение реализации договорных норм международного права (юридическая природа). Советское государство и право. 1991. № 9. С. 116.

21. Гавердовский А.С. Имплементация норм международного прав. Киев : Вища шк., 1980. С. 63.

22. Черниченко С.В. Международное право: современные теоретические проблемы. Москва: Междунар. отношения, 1993. C. 102.

23. Курносова Т.И. Имплементация международно-правовых норм о военных преступлениях и преступлениях против человечности : автореф. дис. ... канд. юрид. наук : спец. 12.00.08. Москва, 2016. С. 18. 
24. Буткевич В.Г., Мицик В.В., Задорожній О.В. Міжнародне право. Основи теорії : підручник. Київ Либідь, 2002. С. 435.

25. Устав Организации Объединенных Наций : принят 26.06.1945 г. URL: http://zakon.rada.gov.ua/laws/show/995_010 (дата звернення: 21.08.2016).

26. Віденська конвенція про право міжнародних договорів: прийнята 23.05.1969. URL: http://zakon.rada.gov.ua/laws/show/995_118 (дата звернення: 20.20.2017).

27. Большой юридический словарь / под ред. А.Я. Сухарева, В.Е. Крутских. 2-е изд., перераб. и доп. Москва: ИНФРА-М, 2004. C. 354.

28. Великий енциклопедичний юридичний словник / за ред. Ю.С. Шемшученка. Київ : Юрид. думка, 2007. С. 439.

\section{Information about the author:} Ivanchenko O. M.

PhD in Law, Associated Professor at the Department of General Theoretical Jurisprudence, National University "Odessa Law Academy” 2, Academychna str., Odessa, 65009, Ukraine 